\title{
Exploring the determinants of an organisational talent culture for a Botswanan local government institution
}

\begin{tabular}{|c|c|}
\hline \multicolumn{2}{|c|}{$\begin{array}{l}\text { Authors: } \\
\text { Refilwe Masale }^{1} \text { (D) } \\
\text { Emmerentia N. Barkhuizen }^{1,2} \text { (D) } \\
\text { Nico E. Schutte }^{1} \text { (D) }\end{array}$} \\
\hline \multicolumn{2}{|c|}{$\begin{array}{l}\text { Affiliations: } \\
{ }^{1} \text { Global Innovative Forefront } \\
\text { Research Entity, Faculty of } \\
\text { Economic and Management } \\
\text { Sciences, North-West } \\
\text { University, Mmabatho, South } \\
\text { Africa }\end{array}$} \\
\hline \multicolumn{2}{|c|}{$\begin{array}{l}{ }^{2} \text { Department of Industrial } \\
\text { Psychology and People } \\
\text { Management, College of } \\
\text { Economics and Business, } \\
\text { University of Johannesburg, } \\
\text { Johannesburg, South Africa }\end{array}$} \\
\hline \multicolumn{2}{|c|}{$\begin{array}{l}\text { Corresponding author: } \\
\text { Emmerentia Barkhuizen, } \\
\text { nbarkhuizen@uj.ac.za }\end{array}$} \\
\hline \multicolumn{2}{|c|}{$\begin{array}{l}\text { Dates: } \\
\text { Received: } 04 \text { Aug } 2020 \\
\text { Accepted: } 15 \text { Apr. } 2021 \\
\text { Published: } 22 \text { July } 2021\end{array}$} \\
\hline \multicolumn{2}{|c|}{$\begin{array}{l}\text { How to cite this article: } \\
\text { Masale, R., Barkhuizen, E.N. \& } \\
\text { Schutte, N.E., 2021, 'Exploring } \\
\text { the determinants of an } \\
\text { organisational talent culture } \\
\text { for a Botswanan local } \\
\text { government institution', Acta } \\
\text { Commercii } 21(1) \text {, a892. } \\
\text { https://doi.org/10.4102/ } \\
\text { ac.v21i1.892 }\end{array}$} \\
\hline \multicolumn{2}{|c|}{$\begin{array}{l}\text { Copyright: } \\
\text { (C) 2021. The Authors } \\
\text { Licensee: AOSIS. This } \\
\text { is licensed under the } \\
\text { Creative Commons } \\
\text { Attribution License. }\end{array}$} \\
\hline \multicolumn{2}{|l|}{ Read online: } \\
\hline 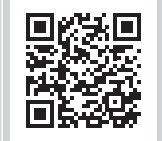 & $\begin{array}{l}\text { Scan this QR } \\
\text { code with your } \\
\text { smart phone or } \\
\text { mobile device } \\
\text { to read online. }\end{array}$ \\
\hline
\end{tabular}

Orientation: Talented employees are essential for the service performance of local government institutions. Conducive organisational talent cultures can enable talent to deliver value-based services that meet public expectations.

Research purpose: To explore the determinants of an organisational talent culture for a Botswanan local government institution.

Motivation for the study: Research on organisational talent culture determinants in Botswana local government institutions is lacking.

Research design, approach and method: This research adopted a quantitative, cross-sectional research design. A self-developed questionnaire was used to measure the organisational talent culture determinants of a Botswana government institution $(N=405)$. The data was analysed using SPSS Statistics software. Descriptive statistics, exploratory factor analyses, linear regression analyses and multivariate analysis of variances (MANOVAs) were applied to the data.

Main findings: The factor analyses provided support for six organisational talent culture determinants: leadership talent mindset, success orientation and strategic intent, institutional values, dynamic operational capabilities, administrative governance and general people management practices. The results showed a weak application of all the organisational talent culture determinants. Leadership talent mindset was a significant predictor of organisational talent culture determinants. Significant differences exist between selected organisational culture dimensions based on the demographic characteristics of the participants.

Practical/managerial implications: The vital role of public sector leadership in enabling a conducive organisational talent culture is emphasised.

Contribution/value-add: This research contributed to the limited empirical knowledge on organisational talent culture determinants in public sector institutions.

Keywords: government institutions; institutional values; leadership talent mindset; organisational talent culture; strategic intent.

\section{Introduction}

The public sector delivery system is one of the most critical methods to improve public welfare (Masuku \& Jili 2019). Local government authorities are expected to provide sustainable services in the right amount and time (Huragu \& Chuma 2019). However, public sector institutions remain under intense scrutiny and criticism as they fail to provide the required services for basic societal needs (Ndevu \& Muller 2018). As a result, the past decade witnessed great public dissatisfaction that further escalated into unrest and destruction of public service properties (Morudu 2017).

To date, a great deal of research determined the causes of poor public service delivery. On a national level, diverse social needs, ageing societies, economic pressures, income equality and unequal access to services are challenging efficient service delivery (Lopes et al. 2017). Masuku and Jili (2019) emphasise the continuous political interference that undermines the effective rollout of public service delivery strategies. Other disrupting factors include flawed management interpretation of policies, corruption and maladministration of resources (Mabitsela 2012), a lack of accountability (Odaro 2012), limited public participation in decision-making (Hasan 2013) and low capacity (Shaidi 2013). For the institution itself, a lack of integrated leadership approaches (Naidoo \& Xollie 2011), ineffective leadership to drive strategies (Gqaji, Proches \& Green 2016), low administrative competence levels (Van Antwerpen \& Fereira 2016) and the brain drain to the 
private sector (Khan 2018) continue to undermine effective public service delivery. Consequently, many public sector institutions are experiencing a human capital crisis because of poor reputation, making it challenging to retain the talented workforce required for sustainable public service provision (Mabope 2018; Thunnissen \& Buttiens 2017).

In the light of the above, the researchers aimed to explore the organisational culture determinants supporting talent management at a Botswanan local government institution. According to Gallardo-Gallardo and Thunnissen (2016), the organisational context is essential when implementing talent management. However, the vast majority of research alludes to public institutional culture inefficiencies that undermine individual and institutional performance. Therefore, local authorities need to rethink organisational culture aspects and refocus counsellors and employees, policies and processes to achieve national goals and priorities (Huragu \& Chuma 2019).

Despite some considerable achievements, Botswanan public sector institutions are constrained by a scarcity of the human capital required to achieve sustainable service performance (Sharma 2010; Tshukudu 2020). Some factors fuelling the talent shortage include poor workforce planning, inadequate performance management and total rewards programmes and neglected talent retention strategies (Diseko 2015; Tshukudu 2020). According to Mohan, Muthaly and Annakis (2015), an institutional culture that enhances the skills, performance ratings and equitable rewards for talented employees can result in a higher retention rate for quality staff in local government. Mokgojwa (2019) found that a talent management culture should consist of management support, strategic direction, physical workspace and resources, safety and security and diversity management to support occupational talent management. An organisational culture that promotes talent management encapsulates a strong talent value proposition inclusive of a compelling organisational and employment brand and a properly assembled talent career life cycle (Saurombe 2017). A healthy organisational culture is essential for both employee and public sector outcomes (ZainUl-Abidin et al. 2020). Therefore, research on organisational talent culture determinants for a Botswanan public sector institution is imperative.

This research addresses the following specific research questions:

- What are the determinants of an organisational culture to support talent management in the government institution?

- How do employees perceive the determinants of the current organisational talent culture in the local government institution?

- What is the relationship between government leadership talent mindset and organisational talent culture determinants? Are there any significant differences between the perceived organisational talent culture determinants based on the demographic characteristics of public sector officials?
This research article is structured as follows. Firstly, a literature review is presented to conceptualise talent management in the public sector organisational culture context. This is followed by discussing the organisational talent culture components identified by the researchers for the public sector. The research design is then explained, followed by a presentation of the results obtained. The research article concludes with a discussion of the results as well as future recommendations for managers.

\section{Literature review}

\section{Talent management in the context of organisational culture}

Organisational culture is a complex concept to define within the public sector, given the context and tradition of a country and institution (Lopes et al. 2017). In simple terms, organisational culture refers to how things are done in an organisation (Lundy \& Cowling 1996). In a broader sense, organisational culture includes the values, beliefs and principles of organisational members (Schein 1990). Organisational culture manifests in routine behaviour, norms, values, philosophy, rules and feelings acceptable in an organisation (Martins \& Terblanche 2003). There is some evidence that national culture influences the organisational culture, affecting talent management (Kravariti 2016; Stan 2012).

Most of the talent management definitions to date revolves around the concepts of 'attracting', 'developing', 'leading' and 'retaining' key and competent skills (see Barkhuizen \& Gumede 2021). Bwowe (2016) proposes that talent management should be leveraged as a strategic, operational priority in public sector institutions, aligned with its overall goals and supported by top management to attract and retain talent. Likewise, Girma (2016) considers organisational culture as a strategic and coherent approach to the organisation's critical assets, where people work together to attain set objectives. The available global research shows that public sector institutions still need to embrace a talent management culture to capitalise on the benefits thereof (Thunnissen \& Buttiens 2017). The bureaucratic nature of local authorities and lack of participation in decisionmaking reduce employee motivation and performance (Krivokapic \& Kavaric 2015). Talented individuals will not easily fit into this organisational culture as they value autonomy in their workspace (Hedström \& McGee 2016).

Painter-Morland et al. (2019:139) attempt to define talent management in the context of organisational culture by referring to 'material and language-based practices influencing the expressions, words, practices and symbolic behaviour of individuals while making sense of work projects'. The definition of Painter-Morland et al. (2019) presents a more personal approach towards talent management by considering the unique social and cultural backgrounds of individuals. Moreover, dominant elitist organisational culture perspectives to talent management are 
challenged to allow for an inclusive talent approach whereby all employees are considered of potential value to the organisation (Dimitrov 2015; Jooss et al. 2019).

Swailes, Downs and Orr (2014) advise that inclusive talents need to be deployed in a position that best fits those talents. This requires an ethical and socially responsible implementation of talent practices, including fair talent identification practices, realistic and non-discriminatory talent descriptions, the provision of visible talent management programmes and monitoring the progress and well-being of employee talent (Swailes 2020). Talent culture also plays a mediating role between talent identification, talent competence development and talent retention (Dass, Muthaly \& Annakis 2015). Therefore, organisational culture should be evident in every function of talent management, ranging from evaluation, development and deployment to talent retention and succession planning (Meng et al. 2016).

Based on the preceding, the researchers define organisational talent culture as a workplace underpinned by the values that talented employees can relate to, enabling them to flourish and make a valuable contribution through optimal performance to achieve strategic institutional objectives. Although many models, frameworks and theories exist to explain organisational culture in various work domains, research on its determinants supporting talent management remains scarce. Likewise, escalating research on talent management has yet to reach a consensus on the desirable policies and practices to optimise a talented workforce (Meyers 2020). Based on the underlying principles of organisational culture and available talent management practice, the researchers identified six dimensions that could establish an organisational talent culture in the Botswanan local government institution. These determinants are explored in the section that follows.

\section{Determinants of organisational talent culture for public sector institutions}

\section{Leadership talent mindset}

Leadership and organisational culture are two concepts that are many times used interchangeably (Tsai 2011). According to Magada and Govender (2016), the type of leadership exercised in public sector institutions is essential for improving service delivery. Yosinta (2016) further asserts that participative and appropriate leadership and management practice effectively achieve high performance in the public services, rather than transformational culture shifts. Transformational leadership appears to be the catalyst for positive organisational cultures in non-profit public sector institutions (Hinds 2019). Available research in the Botswanan context shows a clear difference between the leadership quality and service performance in public sector institutions (Hope 2003). Public sector institutions characterised by high leadership efficiency, organisational objectives, strategic planning and a vision statement are significantly more effective in their service delivery (see Hope 2003). Moreover, ethical leadership and the display of moral values are essential for sustaining Botswanan government institutions (Cheteni \& Shindika 2017).
The linkage between leadership and talent management is of great importance for emerging markets where economies are moving from being more labour-intensive to a knowledgebased society (Betchoo 2014). The leadership talent mindset is the conviction that talent is essential for the organisation and contributes to an organisational culture that breeds competitive advantage, benefitting individuals and organisations (Welby-Cooke 2010). The leadership talent mindset contributes significantly to an energised and healthy workforce (Pienaar 2013). Diseko (2015) found that the leadership talent mindset is one of the main factors contributing to the retention of public sector teachers in Botswana. Rudhumbu and Maphosa (2015) caution that the practice of talent management is neglected in Botswana, partially because of a lack of management knowledge and competence to implement talent management programmes. Consequently, the need for more stakeholder (i.e. leadership) involvement in talent management is essential to harness the development of Africa's workplace talent (Anlesinya, DarteyBaah \& Amponsah-Tawiah 2019).

\section{Organisational values}

Organisational values form the foundation of any institution's culture (Ertosun \& Adiguzel 2018). Values indicate what is important to people in a given cultural context (Pereira, Baranauskas \& Liu 2015) and instrumental in 'determining, guiding and informing behaviour' (MacCarthaigh 2008:x). Public administrators use a combination of 'ethical, professional, democratic, and human values' to maintain their legitimacy (Molina \& McKeown 2012:375). More specifically, public sector values include personal credibility, professional competence, respect for democratic principles and the ability to maintain positive relationships with society (Molina \& McKeown 2012). Ethics and integrity are essential to instil public trust (Andersson 2019).

According to Guthridge, Komm and Lawson (2008), a strong culture reinforces the organisation's value proposition and cultivates knowledge, hard work, courage, risk-taking and creativity. Ştefănescu and Pânzaru (2009) advise that public sector institutions need to create new modern values (i.e. competence, transparency, responsibility, efficiency) to meet public service standards. Saurombe (2017) found that a talent value proposition influences public sector institutions' ability to attract and retain competent workers. Talented employees appear to be more likely to seek employment in line with their values, such as fairness, openness, transparency and friendly workplaces (Molobye 2020).

There appears to be a reciprocal relationship between leadership and cultural values. According to Jan and Maqbool (2015), cultural values shape leadership decisions over time. Leaders have their own set of personal values that will drive their value creation for the organisation (Ertosun \& Adiguzel 2018). According to Zydziunaite (2018), there are four principles of value-based leadership: self-reflection, balance, true self-confidence and genuine humility. The competing values of democracy and bureaucracy in the public sector 
environment require leaders to redefine old values to guide employees more effectively (Molina 2009). Osupile and Makambe (2021) found that an institutional value such as trust improves knowledge sharing in a Botswanan government department.

\section{Strategic intent and success orientation}

Culture plays an important role in the success or failure of any organisation (Gavric, Sormaz \& Ilic 2016). Organisational culture acts as an inner strength to the company and should be aligned with the business strategy to ensure success and competitiveness (Eaton \& Kilby 2015; Ghannay \& Mamlouk 2015). The strategic management of public sector institutions is gaining more attention because of public management reforms (Höglund et al. 2018). Alford and Greve (2017) argue that New Public Management (NPM) principles such as value creation, the environment and organisational capabilities help drive public sector institutions' strategic direction. Applied within the Botswanan context, the NPM contributed to a significant improvement in public service delivery by implementing performance management systems (Dzimbiri 2008). New Public Management further enhanced the strategic management processes by enabling Botswanan ministries to develop more precise goals and objectives to achieve government strategies.

A strategic approach towards public sector management also allows for a culture of innovation (Arundel, Bloch \& Ferguson 2019). A culture of innovation is underpinned by five dimensions: innovative leaders, innovative teams, innovative individuals, a conducive environment and strong connections within the organisations (Euchner 2017). Similarly, Razavi and Attarnezhad (2013) argue that innovation is enhanced through structural forms, adaptability and organisation capability. Trust, a pleasant working environment, management support and customer orientation can further enable innovation (Carmeli \& Spreitzer 2009).

Strategy is an essential enabler for talent management. Organisations that adopt a people-led approach towards talent management focus on people when discussing their strategy (Aarnio \& Kimber 2016). Talent management practices that are strongly aligned with institutional strategies are more likely to achieve its business strategies and customer satisfaction (Bethke, Mahler \& Staffelbach 2011). Sadeli (2012) found that leadership, combined with talent management and organisational culture, enhances employee engagement. By establishing a conducive organisational culture, leaders can deploy appropriate talent management strategies to enable talent development and succession planning and promote personal growth mindsets to support communities (Damer 2020). Future-focussed leaders are, therefore, essential to bring success in public systems (Reimers-Hild 2018).

\section{Administrative governance and dynamic operational capabilities}

Organisational culture reflects the administrative or bureaucratic culture in public sector institutions (Alom 2020).
According to Dwivedi (2005), the administrative culture is strongly influenced by the political culture and values, which further modulates government employees' behaviour. Public sector effectiveness and functioning are also determined by organisational capacity (Piña \& Avellaneda 2017). Stenvall and Virtanen (2017) believe that intelligent public organisations combine leadership, strategy and foresight, people, partnerships and resources, and organisational processes. Administrative cultures can also be manipulated and altered by management and leadership preferences in government institutions (Jamil, Askvik \& Hossain 2013:379). Pečarič (2013) argues that new leadership approaches to public administration can lead to responsible behaviour, reduction of undesirable practices, rational use of budgets, building trust, cultivation of favourable working conditions and accountability. According to Adeyemi et al. (2012), a culture of accountability matters for local authorities' improved performance.

The importance of high-performing and dynamic organisations in facilitating talent performance has been reported. Some studies (see Padhi 2017; Uddin, Luva \& Hossian 2013) show that culture can only affect performance and productivity in dynamic contexts. Similarly, Qi and Wang (2016) proposed that high-involvement work systems are crucial to service performancein thepublicsector. This requiresa democratisation of organisational behaviour where employees can participate in government institutions' decision-making processes (Irawanto 2015). An enabling environment where local government' staff can provide inputs can contribute to a collaborative culture (Tuurnas et al. 2019).

Local government employees' talent management should be different, less bureaucratic and more client oriented (LunaArocas \& Lara 2020). Bureaucratic cultures limit public sector leaders to empower employees and foster knowledgesharing behaviours for efficient operational practice (Hendryadi et al. 2019). Mosweunyane (2013) coined the term Botswaucracy to emphasise the misuse of bureaucracy in Botswanan public educational settings and the adverse outcomes. Molebatsi (2012) advocates for a more creative approach where employees can participate and challenge unpopular government policies and practices in Botswana.

\section{General people management practice}

Knies et al. (2018) view public sector employment as labour intensive, with the public sector worker performance as essential to effective service delivery. Consequently, more emphasis should be placed on human capital for public sectorreformand furtherimproved services(Yahiaoui,Anser\& Lahouel 2015). Burke, Allisey and Noblet (2013) highlight why public sector institutions should increase their focus on people management practice. Firstly, there is a lack of research attention on people management practices in the public sector domain. The growing importance of public sector services moves the attention to the employees who need to contribute to these services. According to Burke et al. (2013), the efficient management of people in public sector 
agencies are constrained because of employee lay-offs, salary freezes and a scarcity of core skills.

Organisational culture and management practices are strong contributors to public service' governance effectiveness (Singh 2012). The institutions' culture and practices influence the operationalisation of people management functions (Kosiorek \& Szczepańska 2016). Jerome (2013) found that organisational culture was a significant predictor of human resource management in non-governmental organisations (NGOs). In particular, matching employee and institutional characteristics is essential for talent retention and sustaining public sector institutions' performance (Austin \& Zachny 2015). The application of best people management practices (i.e. recruitment, selection, training, career development, performance appraisal and compensation and benefits) further aids a strategic tool to retain talented public employees (Fahim 2018).

Conversely, a misaligned organisational culture can result in inconsistent strategic people management practices and poor organisational outcomes for institutions (Harrison \& Bazzy 2017). A study by Seitio-Kgokgwe et al. (2016) showed that factors such as inadequate planning, low deployment, a lack of comprehensive retentions strategies and poor working conditions contributed to the inability of Botswana's public health institutions to attract and retain skilled staff. Van Antwerpen and Fereira (2016) emphasise the importance of equipping administrative staff with the necessary skills to prevent cost increases, higher community frustration levels and a lack of foreign investment.

To summarise, the literature review emphasised the essential components of an organisational talent culture that could be considered in the public sector domain. In the light of the limited research of organisational talent culture elements, the literature review provides some direction in applying these determinants in the public sector domain. The critical role of leadership in facilitating a conducive organisational talent culture is evident in all organisational culture domains. Likewise, establishing institutional values as a core foundation of a talent culture can strengthen public sector value propositions essential for the attraction and retention of talent. The 'New Public Management' movement provides functional principles and avenues for public sector institutions to achieve strategic objectives through valueadding services. The proper implementation and execution of administrative governance and general people management practices are essential to enable public sector officials to deliver quality services.

\section{Research design \\ Research approach and philosophy}

This research followed a quantitative research design by using surveys to gather the data. The study was crosssectional, whereby data were collected over a short-term period. This type of research design is ideal for testing the relationship between variables (Field 2019). This research falls within the positivist research paradigm. Positivism implies that the researcher relies on factual knowledge and is limited to data collection and data interpretation in an objective way (Collins 2010).

\section{Respondents}

The target population for this study was employees of a selected Botswanan local government institution. A total of 650 questionnaires were distributed, with 405 questionnaires completed and returned. This represented a response rate of $62.30 \%$. The respondents were primarily female $(55.3 \%)$, married (51.34\%) and Setswana speaking (99.8\%). Most of the participants were aged between 40 and 49 years (66.4\%), had a certificate and diploma as their highest level of educational qualification (48.63\%) and were employed on an operational level (39.76\%). The participants mainly had work experience of between 14 and 29 years (39.76\%). About 71.6\% did not have a chance for promotion in the last 5 years, although $90.6 \%$ work between 31 and 40 hours per week.

\section{Research procedure}

The researchers obtained permission from the town clerk (accounting officer) of the relevant local government institution to execute the study. Formal procedures to meet the respective local government council's management were strictly followed and adhered to after receiving approval to conduct the study. The purpose of the meetings was to explain how the research will be conducted. The questionnaire was randomly distributed as a hard copy to the respondents through the supervisors and heads of departments.

\section{Measuring instrument}

The researchers developed a questionnaire considering the organisational culture elements that should enable talent management in the local government institution. The questionnaire was based on the theoretical framework identified and discussed for the present study. The questionnaire consisted of 31 items and measured six dimensions: leadership talent mindset (four items, i.e. 'The leadership in the institution is generally considered to exemplify mentoring.'), strategic intent and success orientation (nine items, i.e. 'The institution emphasise achievement and goal accomplishment.' and 'The institution defines success as having innovative services.'), values (i.e. six items, i.e. 'In this institution everyone treats one another with respect.'), dynamic institutional capabilities (i.e. four items, i.e. 'The institution is a dynamic place where people are achievement orientated.'), people management practices (four items, i.e. 'The institution emphasises human development.') and administrative governance (i.e. four items, 'The institution has a controlled and structured work environment.'). Responses were measured on a 6-point Likert scale ranging from $1=$ strongly disagree to $6=$ strongly agree. The questionnaire was distributed to subject matter experts to ensure face and content validity. The reliability of the questionnaire was established in the present study. 


\section{Statistical analysis}

The statistical analyses were conducted by using the Statistical Package for the Social Sciences (SPSS -27, 2021). Descriptive statistics (i.e. frequencies, means, standard deviation, skewness and kurtosis) were applied. Exploratory factor analysis was used to determine the factor structure of the organisational talent culture questionnaire. Cronbach's a coefficients $\geq 0.70$ (Cohen 1988) were used as the guidelines to determine the questionnaire's reliability. Hierarchical regression analyses were applied to determine the predictive relationship between the variables (i.e. leadership and organisational talent culture dimensions). Rumsey (2016) proposes the following guidelines for interpreting the magnitude of ' $r$ ' in the predictive relationship: $r \geq 0.30, p \leq 0.05$ (a weak linear relationship), $r \geq$ $0.50, p \leq 0.05$ (moderate relationship) and $r \geq 0.70, p \leq 0.05$ (a strong relationship). Multivariate analyses of variance (MANOVA) were used to determine the relationships between respondents' organisational talent culture perceptions based on their demographic characteristics. The following guidelines of Cohen (1988:283) were used for the interpretation of effect sizes: 0.0099 constitutes a small effect, 0.0588 a medium effect and 0.1379 is a large effect. Post hoc tests confirm the differences between the respondents' organisational talent culture perceptions based on demographic characteristics.

\section{Ethical considerations}

The researchers obtained ethical approval from NorthWest University (Ethics number: NWU-00565-19-A4) before the study's commencement. Participation in the study was voluntary, and confidentiality was maintained at all times.

\section{Results}

The results reveal a Kaiser-Meyer-Olkin (KMO) measure of sampling adequacy of $0.954(p=0.000)$, which, according to the guidelines of Hair et al. (2010), provides that a $\mathrm{KMO} \geq 0.60$ be adequate for factor analysis. A subsequent principal component exploratory factor analysis by using varimax rotation resulted in six underlying factors for the organisational talent culture questionnaire, which explained $79.509 \%$ of the total variance. Three items were deleted because of problematic loadings. The factors were labelled as follows: strategic intent and success orientation (Factor 1), institutional values (Factor 2), general people management practices (Factor 3), dynamic operational capabilities (Factor 4), administrative governance (Factor 5) and leadership talent mindset (Factor 6). All items show acceptable loadings. The results of the Varimax rotation are reported in Table 1.

The descriptive statistics and reliabilities of the factors are reported next. Table 2 shows acceptable to excellent reliabilities for the underlying factors of the organisational talent culture measure. On average, the results showed a weak to mediocre demonstration of organisational talent culture dimensions in the institution. The institutional values

TABLE 1: Rotated component matrix for the organisational talent culture questionnaire.

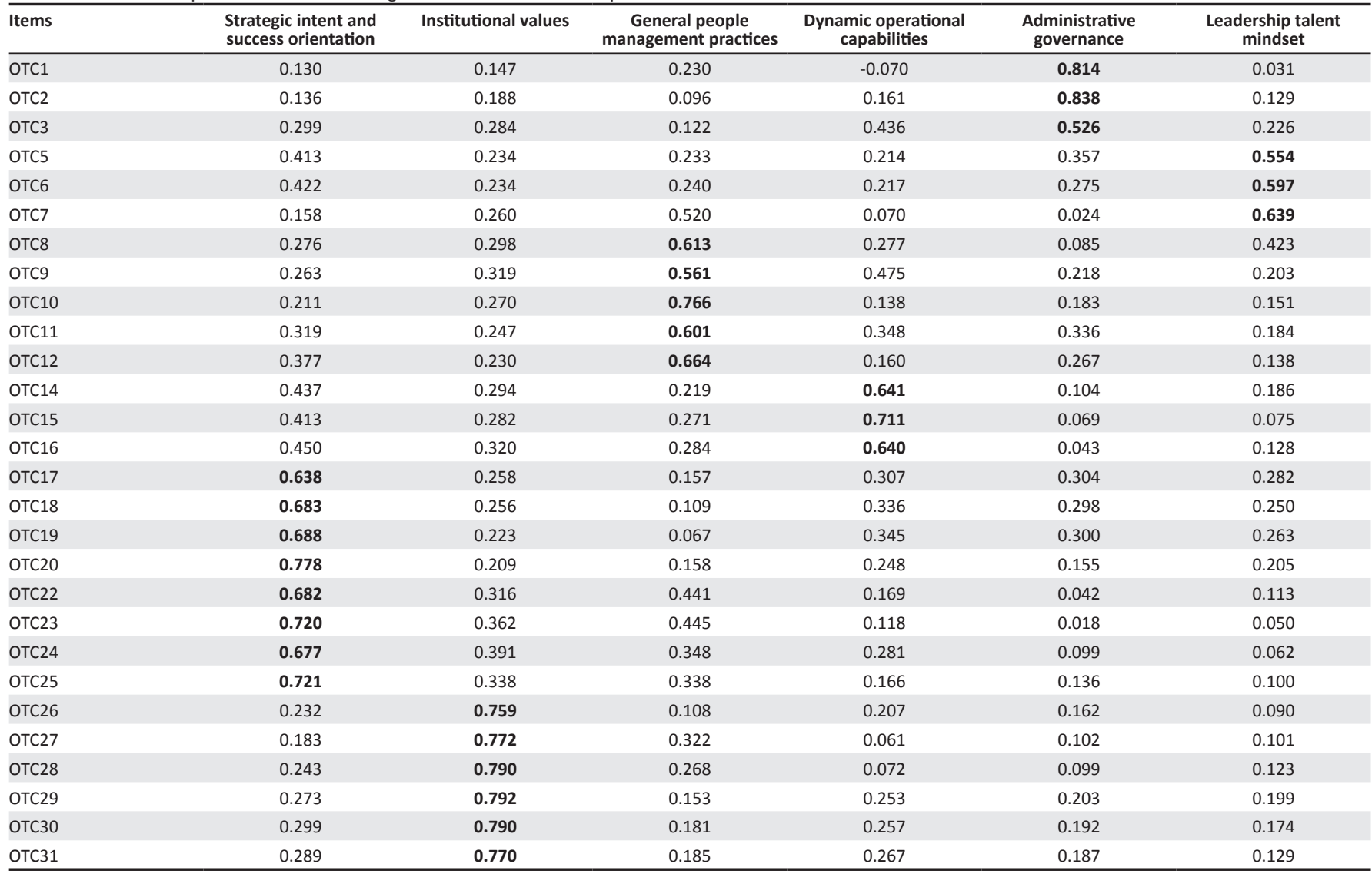

Note: Values highlighted in bold indicate the items that loaded per factor. 
were low, followed by poor people management practices and a lack of strategic intent and success orientation. The organisational talent culture further reflected mediocre administrative governance and a poor performance culture relating to a lack of dynamic institutional capabilities. Finally, the results also reflect a poor leadership talent mindset for creating an organisational talent culture for the public sector institution. Item analyses were performed to detect the contributing aspects of the weak organisational talent culture. The participants believed that the absence of clear institutional values resulted in inadequate guidelines and rules for employee conduct. Furthermore, there is a lack of focus on the innovation of products, services and processes on all institutional levels, contributing to inefficient institutional operational dynamics. Leadership is also failing to give strategic direction and connect the long-term vision with individuals' daily performance requirements. Respondents therefore appear to have the conviction that the institution is not results driven or achievement orientated.

Next regression analyses were conducted to determine how the leadership talent mindset influences the selected government institution's talent culture. The results are reported in Table 3.

The results shown in Table 3 show the following:

- The prediction model for leadership talent mindset and strategic intent and success orientation is statistically significant, $F_{(1,404)}=343.493$, and accounted for approximately $73.6 \%$ of the variance in strategic

TABLE 2: Descriptive statistics of the organisational talent culture questionnaire.

\begin{tabular}{|c|c|c|c|c|c|}
\hline $\begin{array}{l}\text { Organisational talent culture } \\
\text { dimensions }\end{array}$ & Mean & SD & Skewness & Kurtosis & $\alpha$ \\
\hline $\begin{array}{l}\text { Strategic intent and success } \\
\text { orientation }\end{array}$ & 2.8091 & 1.20245 & 0.573 & -0.639 & 0.953 \\
\hline Institutional values & 2.5935 & 1.12968 & 0.727 & -0.158 & 0.946 \\
\hline $\begin{array}{l}\text { General people management } \\
\text { practices }\end{array}$ & 2.7322 & 1.17073 & 0.514 & -0.591 & 0.914 \\
\hline Dynamic operational capabilities & 2.9697 & 1.23975 & 0.608 & -0.450 & 0.738 \\
\hline Administrative governance & 3.1706 & 1.06478 & 0.680 & 0.060 & 0.912 \\
\hline Leadership talent mindset & 2.9318 & 1.11825 & 0.445 & -0.488 & 0.800 \\
\hline
\end{tabular}

SD, standard deviation. intent and success orientation $\left(R^{2}=0.541 ; \Delta R^{2}=0.540\right)$. The relationship is positive, which implies that a poor leadership talent mindset can result in a lack of strategic intention and success orientation for the institution. The prediction effect is strong.

- The prediction model for leadership talent mindset and institutional values is statistically significant, $F_{(1,404)}=185.512$, and accounted for approximately $62.3 \%$ of the variance in values $\left(R^{2}=0.388 ; \Delta R^{2}=0.386\right)$. The relationship is positive, which implies that a poor leadership talent mindset can result in low institutional values. The prediction effect is moderate.

- The prediction model for leadership talent mindset and dynamic operational capabilities is statistically significant, $F_{(1,404)}=187.632$, and accounted for approximately $62.4 \%$ of the variance in employee participation $\left(R^{2}=0.390 ; \Delta R^{2}=0.387\right)$. The relationship is positive, which implies that a poor leadership talent mindset can result in an institutional culture characterised by low dynamics and limited opportunities for employee participation. The prediction effect is moderate.

- The prediction model for leadership talent mindset and general people management practices is statistically significant, $F_{(1,404)}=426.638$, and accounted for approximately $76.9 \%$ of the variance in general people management practices $\left(R^{2}=0.591 ; \Delta R^{2}=0.590\right)$. The relationship is positive, which implies that a poor talent mindset can result in poor people management practices for the institution. The prediction effect is strong.

- The prediction model for leadership talent mindset and administrative governance is statistically significant, $F_{(1,404)}=161.761$, and accounted for approximately $59.4 \%$ of the variance in general people management practices $\left(R^{2}=0.353 ; \Delta R^{2}=0.351\right)$. The relationship is positive, which implies that a poor leadership talent mindset can result in poor administration governance practices. The prediction effect is moderate.

Next the MANOVA analyses between organisational talent culture dimensions and demographic characteristics of the participants are reported. The results in Table 4 show that

TABLE 3: Regression analyses between leadership talent mindset and organisational talent culture dimensions.

\begin{tabular}{|c|c|c|c|c|c|c|c|c|}
\hline Variable & B & SE & Beta & $T$ & $p$ & $\boldsymbol{R}$ & $R^{2}$ & $\Delta R^{2}$ \\
\hline \multicolumn{9}{|c|}{ Regression analyses: leadership talent mindset and strategic intent and success orientation } \\
\hline (Constant) & - & - & - & - & - & 0.736 & 0.541 & 0.540 \\
\hline Leadership & 0.789 & 0.043 & 0.736 & 18.534 & 0.000 & - & - & - \\
\hline \multicolumn{9}{|c|}{ Regression analyses: leadership talent mindset and institutional values } \\
\hline (Constant) & - & - & - & - & - & 0.623 & 0.388 & 0.386 \\
\hline Leadership & 0.628 & 0.046 & 0.623 & 13.620 & 0.000 & - & - & - \\
\hline (Constant) & - & - & - & - & - & 0.624 & 0.390 & 0.387 \\
\hline Leadership & 0.686 & 0.050 & 0.624 & 13.698 & 0.000 & - & - & - \\
\hline \multicolumn{9}{|c|}{ Regression analyses: leadership talent mindset and general people management practices } \\
\hline (Constant) & - & - & - & - & - & 0.769 & 0.591 & 0.590 \\
\hline Leadership & 0.805 & 0.039 & 0.769 & 20.655 & 0.000 & - & - & - \\
\hline \multicolumn{9}{|c|}{ Regression analyses: leadership talent mindset and administrative governance } \\
\hline (Constant) & - & - & - & - & - & 0.594 & 0.353 & 0.351 \\
\hline
\end{tabular}

$\mathrm{SE}$, standard error. 
TABLE 4: Multivariate analyses of variance between organisational talent culture and demographics.

\begin{tabular}{|c|c|c|c|c|c|c|}
\hline Variables & Value & $F$ & $\begin{array}{c}\text { Hypothesis } \\
\text { df }\end{array}$ & Error df & Sig. & $\begin{array}{l}\text { Partial eta } \\
\text { squared }\end{array}$ \\
\hline Gender & 0.977 & 1.119 & 6.000 & 282.000 & 0.351 & 0.023 \\
\hline Age & 0.920 & 1.319 & 18.000 & 792.445 & 0.168 & 0.027 \\
\hline Qualification & 0.845 & 1.602 & 30.000 & 1114.000 & $0.022 *$ & 0.033 \\
\hline Job level & 0.793 & 2.775 & 24.000 & 971.036 & $0.000 *$ & 0.056 \\
\hline $\begin{array}{l}\text { Years of work } \\
\text { experience }\end{array}$ & 0.850 & 1.278 & 36.000 & 1219.153 & 0.127 & 0.027 \\
\hline $\begin{array}{l}\text { Years in } \\
\text { current job }\end{array}$ & 0.842 & 1.635 & 30.000 & 1114.000 & $0.017 *$ & 0.034 \\
\hline Promotion & 0.930 & 1.152 & 18.000 & 792.445 & 0.296 & 0.024 \\
\hline $\begin{array}{l}\text { Hours of work } \\
\text { per week }\end{array}$ & 0.938 & 1.010 & 18.000 & 792.445 & 0.446 & 0.021 \\
\hline
\end{tabular}

*, Denotes significant differences.

respondents significantly differ in their perceptions of organisational talent culture based on their education level, job level and years employed in their current job. The results were further explored by applying post hoc analyses.

The Wilks' $\lambda$ for educational qualification is equal to $0.845\left(F_{(30,1114)}=1.602, p \leq 0.05\right)$. Analyses of each dependent variable, by using a Bonferroni-adjusted $\alpha$ level of 0.025 , show that respondents differ in terms of general people management practices $\left(F_{(5,400)}=5.583, p \leq 0.05\right.$, partial $\left.n^{2}=0.909\right)$, leadership talent mindset $\left(F_{(5,400)}=4.553, p \leq 0.05\right.$, partial $\left.n^{2}=0.074\right)$, strategic intent and success orientation $\left(F_{(5,400)}=3.722, p \leq 0.05\right.$, partial $\left.n^{2}=0.062\right)$ and operational dynamics $\left(F_{(5,400)}=5.839, p \leq 0.05\right.$, partial $\left.n^{2}=0.094\right)$. Post hoc analyses showed that those with a Cambridge qualification (secondary school qualification) experienced poorer people management practices, leadership, strategic intent and success orientation and dynamic institutional capabilities compared with those with a diploma and bachelor's degree as their highest level of education. The effects were medium.

The Wilks' $\lambda$ for job level is equal to $0.793\left(F_{(24,971.036)}=2.775\right.$, $p \leq 0.05)$. Analyses of each dependent variable, by using a Bonferroni-adjusted $\alpha$ level of 0.025 , show that respondents differ in terms of administrative governance $\left(F_{(4,401)}=5.049, p \leq 0.05\right.$, partial $\left.n^{2}=0.067\right)$, general people management practices $\left(F_{(4,401)}=7.576, p \leq 0.05\right.$, partial $\left.n^{2}=0.097\right)$, leadership talent mindset $\left(F_{(4,401)}=6.492, p \leq 0.05\right.$, partial $\left.n^{2}=0.084\right)$, strategic intent and success orientation $\left(F_{(4,401)}=9.209, p \leq 0.05\right.$, partial $\left.n^{2}=0.115\right)$, values $\left(F_{(4,401)}=5.570, p \leq 0.05\right.$, partial $\left.n^{2}=0.703\right)$ and dynamic institutional capabilities $\left(F_{(4,401)}=7.644, p \leq 0.05\right.$, partial $\left.n^{2}=0.098\right)$. The results show that operational staff experience a significant poorer level of administrative governance and general people management practices compared with senior management levels. Operational-level staff further experienced a significant poorer level of dynamic institutional capabilities compared with the rest of job levels (i.e. senior management, middle management, lower level management and supervisory level) and strategic intent and success orientation (i.e. senior management, middle management and lower level management). Operational-level employees experience a significant lower level of leadership talent mindset compared with middle management. All effects are medium.

The Wilks' $\lambda$ for years in current job is equal to 0.734 $\left(F_{(30,1114)}=1.635, p \leq 0.05\right)$. Analyses of each dependent variable, by using a Bonferroni-adjusted $\alpha$ level of 0.025 , show that respondents differ in terms of administrative governance $\left(F(5,400)=5.008, p \leq 0.05\right.$, partial $\left.n^{2}=0.081\right)$, leadership talent mindset $\left(F_{(5,400)}=3.061, p \leq 0.05\right.$, partial $\left.n^{2}=0.051\right)$ and employee participation $\left(F_{(5,400)}=3.224, p \leq 0.05\right.$, partial $n^{2}=0.054$ ). Those working between 0 and 5 years in their current job experienced more efficient administrative governance, leadership talent mindset and employee participation compared with those working between 12 and 17 years in the institution. The effects for administrative governance and employee participation are medium, whereas the effect for leadership talent mindset is small.

\section{Discussion}

This research's main objective was to explore organisational culture determinants supporting talent management in a Botswanan local government institution. The factor analyses supported six dimensions that should form part of the government institution's organisational culture to support talent management: strategic intent and success orientation, institutional values, general people management practices, employee participation, administrative governance, dynamic institutional capabilities and leadership talent mindset. These factors support the NPM paradigm that government institutions should adopt a more strategic process to create public value through its critical organisational capabilities: human capital (Alford \& Greve 2017; Höglund et al. 2018).

The participants in this study perceived a weak demonstration of the identified organisational talent culture dimensions. These findings contrast Meng et al. (2016) who advocate that organisational culture should be present in all talent management functions. The absence of values destabilises the foundation on which the institution's talent culture should be built (Ertosun \& Adiguzel 2018). Consequently, the government institution will find it challenging to display the required individual behaviour to deliver trustworthy and ethical services to the public (Andersson 2019; Molina \& McKeown 2012; Pereira et al. 2015). Moreover, a lack of institutional values can also prevent the ethical and socially responsible implementation of talent management practices to ensure a healthy and sustainable workforce (Swailes 2020). Without a strong value foundation, the government institution will fail to create the talent value proposition required to attract and retain talent (Saurombe 2017). Molobye (2020) mentioned that talented employees are more likely to associate themselves with a workplace that embraces their values.

The organisational culture influences the operationalisation of people management functions (Kosiorek \& Szczepańska 
2016). As evidenced in the present study, inadequate administrative governance systems and a lack of dynamic operational capabilities undermine talent performance and productivity (Adeyemi et al. 2012). The results also support the notion of Botswaucracy (see Mosweunyane 2013), whereby bureaucracy in public sector workplace settings is strengthened to the detriment of employees and employers. Establishing a favourable and collaborative administrative work environment is essential to enable employee participation, responsible behaviour and accountability (Pečarič 2013; Tuurnas et al. 2019). In particular, a misaligned organisational talent culture, as uncovered in the present study, undermines strategic people management practices (Harrison \& Bazzy 2017) and results in low deployment, inadequate planning, a lack of comprehensive retentions strategies and poor working conditions (Seitio-Kgokgwe et al. 2016). Therefore, the government institution needs to be less bureaucratic and refocus talent management processes and procedures to achieve national goals and priorities (Huragu \& Chuma 2019; Luna-Arocas \& Lara 2020).

The sustainability of any local government institution, to a large extent, depends on its strategic direction (Eaton \& Kilby 2015; Ghannay \& Mamlouk 2015). The lack of strategic direction and success orientation of the government institution in this study limits the institutional reform and transformation required to achieve NPM principles (Höglund et al. 2018). As such, the government institution might fail to meet the performance requirements as set out by the NPM for Botswana and execute broader national strategies (Alford \& Greve 2017). The lack of strategic direction undermines the development of personal talent growth mindsets required to support the wider public (Damer 2020). Government institutions should create a 'talent management language' (Painter-Morland et al. 2019) that leverages talent management as a strategic organisational priority (Bwowe 2016) in the pursuit of overarching institutional goals.

In this study, the leadership talent mindset had a significant role in how the organisational talent culture translated in the government institution. The results showed that the poor leadership talent mindset was a significant predictor of a lack of institutional strategic intent and success orientation, limited employee participation, poor administrative governance, dynamic organisational capabilities and weak institutional values. These results support various other studies that leadership is the catalyst for establishing a valueadding public sector service culture (see Magada \& Govender 2016; Yosinta 2016). The leadership talent mindset further emphasises a commitment to attracting and retaining the human capital required to breed sustainable public sector institutions (Diseko 2015; Welby-Cooke 2010). The results of this research confirm the need to educate leadership more in the practice of leadership in Botswanan government institutions (Rudhumbu \& Maphosa 2015).
Given the significance of individual characteristics in establishing organisational cultures (see Lopes et al. 2017), the researchers also explored whether significant differences exist between the perceived organisational talent culture dimensions based on their demographic characteristics. The study results revealed that organisational talent culture tends to be neglected when it comes to lower-job-level employees, those with a lower level of employment and those employed for a shorter time in the institution. The results also show a disconnect between top-level leadership experience as talent management effectiveness compared with those on lower employment levels. More research studies are required to explore these findings.

\section{Implications of the study}

This research makes valuable contributions on theoretical, methodological and practical levels. From a theoretical point of view, this research contributes to the scarcity of empirical knowledge on talent management in public sector contexts and emerging markets. More specifically, this research provides a practical foundation to determine the maturity of organisational talent culture by focussing on aspects such as the leadership talent mindset, institutional values, strategic intent and success orientation, administrative governance, dynamic institutional capabilities and general people management practices. This research makes an important methodological contribution by providing a reliable questionnaire that can measure an organisational talent culture's components for public sector institutions. Finally, this research makes an important practical contribution by revealing the government institution's talent culture and improvement areas' current status. The absence of a sound institutional value system can translate into undesirable behaviours, undermining effective service delivery. Importantly, this research highlights the need for more leadership engagement to enable a supportive institutional environment for talent management in the government institution. As evidenced in this present study, a lack of leadership talent mindset translated into an institutional culture that does not support talent management. Consequently, government institutions are challenged to attract and retain the human capital required to deliver value-added and sustainable services to the broader public.

\section{Limitations and recommendations for future research}

This research had some limitations. Firstly, the data were obtained from a selected town council in Botswana. Consequently, the results cannot be generalised to other regions in the country. Secondly, the study was crosssectional, which limited the researchers to make cause and effect predictions between the variables over a more extended period. Future studies can benefit from longitudinal studies to track leadership effectiveness over time intervals. Thirdly, this study was limited to quantitative research only. Future research can apply mixed-method research techniques to uncover the contributors to the weak organisational talent culture. Finally, future research can also include more 
predictor variables (i.e. institutional demands and resources for talent culture) and outcome variables (i.e. service performance and employee retention) to develop a holistic model for organisational talent culture within the public sector institutions.

\section{Conclusion}

In conclusion, the research objectives for this study were achieved. Six underlying organisational talent culture factors were identified that other public sector institutions could consider to determine its maturity and readiness to attract and retain talent. This research further emphasises the vital role of public sector leaders in creating a workplace talent culture that will enable public service efficiency and effectiveness. Therefore, public sector leaders are encouraged to take stock of their existing institutional talent cultures as an enabler to achieve national service delivery priorities through talent.

\section{Acknowledgements Competing interests}

The authors declare that they have no financial or personal relationships that may have inappropriately influenced them in writing this article.

\section{Authors' contributions}

R.M. compiled the research article and collected the data. E.N.B. provided editorial inputs and assisted with the data analyses. N.E.S. provided editorial inputs.

\section{Funding information}

The authors received no financial support for the research and authorship. Funding was received from North-West University for the publication of this article.

\section{Data availability}

The data that support the findings of this study are available from the corresponding author, E.N.B., upon reasonable request.

\section{Disclaimer}

The views and opinions expressed in this article are those of the authors and do not necessarily reflect the official policy of any affiliated agency of the authors.

\section{References}

Aarnio, A. \& Kimber, E., 2016, 'Talent management \& strategy: Identifying patterns through a multiple case study', Unpublished masters dissertation, Linköping University, Linköping.

Adeyemi, O.O., Akindele, S.T., Aluko, O.T. \& Agesin, B., 2012, 'Institutionalising the culture of accountability in local government administration in Nigeria', African Journal of Political Science and International Relations 6(4), 81-91. https://doi. org/10.5897/AJPSIR11.127

Alford, J. \& Greve, C., 2017, 'Strategy in the public and private sectors: similarities, differences and changes', Administrative Sciences 35(7), 1-17. https://doi. org/10.3390/admsci7040035
Alom, M.M., 2020, Public sector organisational culture: Experience from frontline bureaucracies, IntechOpen, viewed 12 December 2020, from https://www. intechopen.com/books/a-closer-look-at-organizational-culture-in-action/publicsector-organizational-culture-experience-from-frontline-bureaucracies

Andersson, S., 2019, 'Ethics management strategies in public organisations: The case of Sweden', in 2019 annual conference of the American Society for Public Administration, Washington, DC, March 10, 2019.

Anlesinya, A., Dartey-Baah, K. \& Amponsah-Tawiah, K., 2019, 'Talent management research in Africa: Towards multilevel model and research agenda', African Journal of Economic and Management Studies 10(4), 440-457. https://doi. org/10.1108/AJEMS-12-2018-0371

Arundel, A., Bloch, C. \& Ferguson, B., 2019, 'Advancing innovation in the public sector: Aligning innovation measurement with policy goals', Research Policy 48(3), 789-798. https://doi.org/10.1016/j.respol.2018.12.001

Austin, A. \& Zachny, B., 2015, 'The role of public service motivation and organisational culture for organisational commitment', Management 19(2), 21-34.

Barkhuizen, E.N. \& Gumede, B., 2021, 'The relationship between talent management, job satisfaction and voluntary turnover intentions of employees in a selected job satisfaction and voluntary turnover intentions of employees in a selected https://doi.org/10.4102/sajhrm.v19i0.1396

Betchoo, N.K., 2014, 'The need for effective leadership in talent management in Mauritius', International letters of Social and Humanistic Sciences 27, 39-48.

Bethke, P., Mahler, P. \& Staffenbach, B., 2011, 'Effectiveness of talent management strategies', European Journal of International Management 5(5), 524-539. https://doi.org/10.1504/EJIM.2011.042177

Burke, R.J., Allisey, A. \& Noblet, A., 2013, 'The importance of human resource management in the public sector, future challenges and the relevance of the current collection', in R.J. Burke, A.J. Noblet \& C.L. Cooper (eds.), Human resource management in the public sector, pp. 1-13, Edward Elgar Publishing, Cheltenham.

Bwowe, P.W., 2016, 'Crafting strategies to improve talent management in selected south african municipalities', Unpublished doctoral thesis, North-West University, Mmabatho.

Carmeli, A. \& Spreitzer, G.M., 2009, 'Trust, connectivity, and thriving: Implications for innovative behaviors at work', The Journal of Creative Behavior 43(3), 169-191. https://doi.org/10.1002/j.2162-6057.2009.tb01313.x

Cheteni, P. \& Shindika, E.S., 2017, 'Ethical Leadership in South Africa and Botswana', Brazilian Administration Review 14(2), 1-18. https://doi.org/10.1590/18077692 bar2017160077

Cohen, J., 1988, Statistical power analysis for the behavioural sciences, 2nd edn., Lawrence Erlbaum Associates Publishers, New York, NY.

Collins, H., 2010, Creative Research: The Theory and Practice of Research for the Creative Industries, AVA Publishing, Worthing, West Sussex, United Kingdom.

Damer, L., 2020, 'Successful talent management strategies business leaders use to improve succession planning', Unpublished doctoral dissertation, Walden University, Minneapolis, MN.

Dass, M.M., Muthaly, S. \& Annakis, J., 2015, 'Talent culture's role in talent development among academics: Insights from Malaysian Government linked universities', Journal of Contemporary Issues in Business and Government 21(1), 46-71.

Dimitrov, K., 2015, 'Talent management - An etymological study', Vanguard Scientific Instruments in Management 11(2), 1-31. https://doi.org/10.23862/kiitparikalpana/2015/v11/i2/133099

Diseko, E., 2015, 'The relationship between Talent Management and retention of teachers in Botswana', Unpublished masters dissertation, North-West University, Mmabatho.

Dwivedi, O.P., 2005, 'Administrative culture and values: Approaches', in J.G. Jabbra \& O.P. Dwivedi (eds.), Administrative culture in a global context, pp. 19-36, De Sitter, Ontario.

Dzimbiri, L.B., 2008, 'Experiences in New Public Management in Africa: The case of performance management systems in Botswana', Africa Development XXXIII(4), $43-58$.

Eaton, D. \& Kilby, G., 2015, 'Does your organizational culture support your business strategy?', The Journal for Quality \& Participation 37(4), 4-7.

Ertosun, O.G. \& Adiguzel, Z., 2018, 'Leadership, personal values and organizational culture', in H. Dincer, H. Hacioglu \& S. Yüksel (eds.), Strategic design and innovative thinking in business operations, contributions to management science, pp. 51-74, Springer Basel AG, Basel. https://doi.org/10.1007/978-3-319-77622-4_3

Euchner, J., 2017, 'Creating a culture of innovation', Research-Technology Management 60(6), 10-11. https://doi.org/10.1080/08956308.2017.1373043

Fahim, M.G.A., 2018, 'Strategic human resource management and public employee retention', Review of Economics and Political Science 3(2), 20-39. https://doi. org/10.1108/REPS-07-2018-002

Field, A., 2019, Discovering statistics using SPSS, 4th edn., Sage, London.

Gallardo-Gallardo, E. \& Thunnissen, M., 2016, 'Standing on the shoulders of giants? A critical review of empirical talent management research', Employee Relations 38(1), 31-56.

Gavric, G., Sormaz, G. \& Ilic, D., 2016, 'The impact of organisational culture on the ultimate performance of a company', International Review 4, 25-30. https://doi. org/10.5937/intrev1604025G

Girma, S., 2016, 'The relationship between leadership style, job satisfaction and culture of the organisation', International Journal of Applied Research 2(4), 35-45.

Ghannay, J.C. \& Mamlouk, Z.B.M., 2015, 'Influence of organizational culture on competitive intelligence practice: A conceptual framework', International Journa of Innovation, Management and Technology 6(1), 35-39. https://doi.org/10.7763/ IJIMT.2015.V6.570 
Gqaji, A., Proches, C. \& Green, P., 2016, 'Perceived impact of public sector leadership on road infrastructure service delivery', Investment Management and Financial Innovations 13(3), 51-59. https://doi.org/10.21511/imfi.13(3-2).2016.12

Guthridge, M., Komm, A.B. \& Lawson, E., 2008, 'Making talent a strategic priority', McKinsey Quarterly 1, 48

Hair, J.F., Black, W.C., Babin, B.J. \& Anderson, R.E., 2010, Multivariate data analysis: A global perspective, 7th edn., N.J. Pearson Education, Upper Saddle River, NJ.

Harrison, T. \& Bazzy, J.D., 2017, 'Aligning organisational culture and strategic human resource management', Journal of Management Development 36(10), 1260-1269. https://doi.org/10.1108/JMD-12-2016-0335

Hasan, S.M.M., 2013, 'Organisational culture and participation in Local governance: A study on infrastructure projects under LGSP in Bangladesh', Unpublished masters dissertation, University of Dhaka, Dhaka.

Hedström, L. \& McGee, D.M., 2016, 'Talent management - A study of attitudes among employees', Unpublished masters dissertation, Blekinge Institute of Technology, Blekinge.

Hendryadi, H., Suratna, S., Suryani, S. \& Purwanto, B., 2019, 'Bureaucratic culture, empowering leadership, affective commitment, and knowledge sharing behavio in Indonesian government public services', Cogent Business \& Management 6(1), 1-12. https://doi.org/10.1080/23311975.2019.1680099

Hinds, S., 2019, 'Influence of organisational culture and leadership styles on nonprofit members' commitment', Unpublished doctoral thesis, Walden University, Minneapolis, MN.

Höglund, L., Caicedo, M.K., Mårtensson, M. \& Svärdsten, F., 2018, 'Strategic management in the public sector: How tools enable and constrain strategy making', International Public Management Journal 21(5), 822-849. https://doi.or $\mathrm{g} / 10.1080 / 10967494.2018 .1427161$

Hope, K.R., 2003, 'Employee perceptions of leadership and performance management in Botswana public service', Public Personnel Management 32(2), 301-313. https://doi.org/10.1177/009102600303200209

Huragu, M. \& Chuma, R.M., 2019, 'the impact of organisational culture on public sector performance: A case study of local authorities in Zimbabwe', International Journal of Public Policy and Administration Research, Conscientia Beam 6(1), 33-56.

Irawanto, D.W., 2015, 'Employee participation in decision-making: Evidence from a state-owned enterprise in Indonesia', Management 20(1), 159-172.

Jamil, I., Askvik, S. \& Hossain, F., 2013, 'Understanding administrative culture: Some theoretical and methodological remarks', International Journal of Public Administration 36(13), 900-909. https://doi.org/10.1080/01900692. 2013.837728

Jan, I. \& Maqbool, M., 2015, 'Leadership styles and organisational culture in service sector: An empirical assessment', International Journal of Marketing, Financial services and Management Research 4(2), 104-117.

Jerome, N., 2013, 'Empirical investigation of the impact of organizational culture on human resource management', International Journal of Business and Social Science 2(5), 84-93.

Jooss, S., McDonell, A., Burbach, R. \& Vaiman, V., 2019, 'Conceptualising talent in multi-national hotel corporations', International Journal of Contemporary Hospitality Management 31(10), 3879-3898. https://doi.org/10.1108/ IJCHM-10-2018-0849

Khan, S., 2018, 'Factors attracting and retaining professionals: A comparative study between the private and public sector', Unpublished masters dissertation, North West University, Mmabatho.

Knies, E., Boselie, P., Gould-Williams, J. \& Vandenabeele, W., 2018, 'Strategic human resource management and public sector performance: Context matters', The International Journal of Human Resource Management 22(9), 1902-1917. https:// doi.org/10.1080/09585192.2017.1407088

Kosiorek, D. \& Szczepańska, K., 2016, 'Relationships between organisational culture and human resource management', Jagiellonian Journal of Management 2(3), 205-215.

Kravariti, F., 2016, 'National and organisational culture impact of talent management implementation: Case studies from Greece', Unpublished masters dissertation, University of Manchester, Manchester.

Krivokapic, S. \& Kavaric, A., 2015, 'The role of organisational culture in innovative changes of public administration', in Managing intellectual capital and innovation for sustainable and inclusive society conference, Bari, May 27-29, 2015.

Lopes, N.V., Sa Soares, D., Nielsen, M.M. \& Tavares, A., 2017, 'Research gaps on public service delivery', in ICEGOV '17: Proceedings of the 10th International Conference on Theory and Practice of Electronic Governance, Association for Computing Machinery, New York, NY, United States, March 7-9, 2017, pp. 465-474.

Luna-Arocas, R. \& Lara, F.J., 2020, 'Talent management, affective organizational commitment and service performance in local government', International Journal of Environmental Research and Public Health 17(3), 1-15. https://doi org/10.3390/ijerph17134827

Lundy, O. \& Cowling, A., 1996, Strategic human resource management, Routledge, London.

Mabitsela, N.A., 2012, 'The impact of service delivery on the quality of lives of the community of Protea South, Soweto in Johannesburg in the Gauteng Province', Unpublished masters dissertation, University of Limpopo, Polokwane.

Mabope, N.C., 2018, 'Strategies and practices for effective talent management in the Mangaung Metropolitan Municipality', Unpublished masters dissertation, Central University of Technology, Bloemfontein.
MacCarthaigh, M., 2008, Public service values, Discussion paper, Institute of Public Administration, Dublin

Magada, T. \& Govender, K., 2016, 'Culture, leadership and individual performance A South African public service organization study', paper presented the ICMLG conference, St. Petersburg, 14-15th April, Academic Conferences and Publishing International Limited, Reading, UK.

Martins, E.C. \& Terblanche, F., 2003, 'Building organisational culture that stimulates creativity and innovation', European Journal of Innovation Management 6(1), 64-74. https://doi.org/10.1108/14601060310456337

Masuku, M. \& Jili, N., 2019, 'Public service delivery in South Africa: The political influence at government level', Journal of Public Affairs 19(2), 1-7. https://doi. org/10.1002/pa.1935

Meng, F., Wang, X., Chen, H., Zhang, J., Yang, J., Wang, J. et al., 2016, 'The influence organisational culture on talent management: A case study of a real estate company', Journal of Chinese Human Resource Management 7(2), 129-146.

Meyers, M., 2020, 'The neglected role of talent proactivity: Integrating proactive behavior into talent-management theorising', Human Resource Management Review 30(1), 1-13. https://doi.org/10.1016/j.hrmr.2019.100703

Mohan, M.D., Muthaly, S. \& Annakis, J., 2015, 'Talent culture's role in talent development among academics: Insights from Malaysian government linked universities', Journal of Contemporary Issues in Business and Government 21(1) 46-71. https://doi.org/10.7790/cibg.v21i1.27

Mokgojwa, D.M., 2019, 'The development of a talent risk management tool for academic staff in South African higher education institutions', Unpublished doctoral thesis, North-West University, Mmabatho.

Molebatsi, C., 2012, 'Participatory development planning in Botswana: Exploring the utilisation of spaces for participation', SSB/TRP/MDM 62(1), 9-14.

Molina, A.D., 2009, 'Values in public administration: The role of organisational culture', International Journal of Organization Theory \& Behavior 12(2), 266-279. https://doi.org/10.1108/IJOTB-12-02-2009-B007

Molina, A.D. \& McKeown, C., 2012, 'The heart of the profession: Understanding public service values', Journal of Public Affairs Education 18(2), 375-396. https://doi.org 10.1080/15236803.2012.12001689

Molobye, N.T., 2020, 'Exploring the application of talent return on investment at Sedibeng Water', Unpublished masters dissertation, Southern Business School, Krugersdorp.

Morudu, H.D., 2017, 'Service delivery protests in South African municipalities: An exploration using principal component regression and 2013 data', Cogent Socia Studies 3(1), 1-15. https://doi.org/10.1080/23311886.2017.1329106

Mosweunyane, D., 2013, 'Bureaucracy turned botswaucracy? How bureaucracy is abused in educational organisations in Botswana', Open Journal of Leadership 2(2), 27-35. https://doi.org/10.4236/ojl.2013.22004

Naidoo, G. \& Xollie, T., 2011, 'The critical need for an integrated leadership approach to improve service delivery by the South African Public Service', Journal of US-China Public Administration 8(1), 1-15.

Ndevu, Z. \& Muller, K., 2018, 'A conceptual framework for improving service delivery at local government in South Africa', African Journal of Public Affairs 10(4), 181-195.

Odaro, E.D., 2012, 'Causes of poor service delivery in Africa and their impact on development', Consilience: The Journal of Sustainable Development 7(1), 34-45.

Osupile, K. \& Makambe, U., 2021, 'The nexus between organisational culture and knowledge sharing in a government department in Botswana', International Journal of Public Sector Management 34(2), 118-136. https://doi.org/10.1108/ IJPSM-06-2020-0149

Padhi, P., 2017, 'Organisational culture and employee performance', International Journal of Research in IT and Management 7(5), 77-81.

Painter-Morland, M., Kirk, S., Deslandes, G. \& Tansley, C., 2019, 'Talent management: The good, the bad, and the possible', European Management Review 16(1) 135-146. https://doi.org/10.1111/emre.12171

Pečarič, M., 2013, 'Representative public administration as the modelling behaviour for the new bureaucracy', International Public Administration Review 11(1), 51-79.

Pereira, R., Baranauskas, M.C.C. \& Liu, K., 2015, 'The value of values for $\mathrm{HCl}$ : An informed discussion beyond philosophy', in XIV Brazilian symposium on human factors in computing systems (IHC'15), Salvado, November 3-6, 2015, pp. 430-439.

Pienaar, Y., 2013, 'The relationship between talent mindset, organisational energy and work wellness of employees', Unpublished doctoral dissertation, University of Pretoria.

Piña, G. \& Avellaneda, C., 2017, 'Local government effectiveness: Assessing the role of organizational capacity', Unpublished research paper, viewed 10 January 2020 ,
from https://ostromworkshop.indiana.edu/pdf/seriespapers/2017spr-colloq/ from $h$ ttps://ostrom

Qi, F. \& Wang, W., 2016, 'Employee involvement, public service motivation, and perceived organisational performance: Testing a new model' International Review of Administrative Services84(4),746-764.https://doi.org/10.1177/0020852316662531

Razavi, S.H. \& Attarnezhad, O., 2013, 'Management of organisational innovation', International Journal of Business and Social Science 4(1), 226-232.

Reimers-Hild, C., 2018, 'Strategic foresight, leadership, and the future of rural healthcare staffing in the United States', Jaapa 31(5), 44-49.

Rudhumbu, N. \& Maphosa, C., 2015, 'Implementation of talent management strategies in higher education: Evidence from Botswana', Journal of Human Ecology 49(1), 21-32. https://doi.org/10.1080/09709274.2015.11906820

Rumsey, D., 2016, Statistics for dummies, 2nd edn., John Wiley \& Sons, Inc, Hoboken, NJ. 
Sadeli, J., 2012, 'The influence of leadership, talent management, organizational culture and organizational support on employee engagement', International Research Journal of Business Studies 5(3), 1-21.

Saurombe, M.D., 2017, 'Management perspective on a talent value proposition for academic staff in a South African Higher Education Institution', Unpublished doctoral dissertation, North-West University, Mmabatho.

Schein, E.H., 1990, 'Organisational culture', American Psychologist 45(2), 109-119. https://doi.org/10.1037/0003-066X.45.2.109

Seitio-Kgokgwe, O., Gauld, R.D., Hill, P.C. \& Barnett, P., 2016, 'Analysing the stewardship function in Botswana's health system: Reflecting on the past, looking to the future', International Journal of Health Policy and Management 5(12), 705-713.

Shaidi, E.W., 2013, 'Investigation into causes of service delivery protests in municipalities: A Case of Nelson Mandela Bay Municipality', Doctoral thesis, Nelson Mandela University, Gqeberha.

Sharma, K.C., 2010, 'Role of local government in Botswana for effective service delivery: Challenges, prospects and lessons', Commonwealth Journal of Local Governance 6, 1-8.

Singh, A.K., 2012, 'Impact of the HRM practices and organisation culture on manageria effectiveness in public sector organisations in India', Agricultural Econonomics Czech 56, 379-386. https://doi.org/10.17221/64/2010-AGRICECON

Stan, L., 2012, 'Talent management and the cultural influences on human resource management processes: A comparison on HRM practices between companies from Sweden and Romania', Unpublished masters dissertation, University of Gothenburg Gothenburg.

Ştefănescu, C. \& Pânzaru, S., 2009, 'Specific features of the organisational culture of the local government', Review of General Management 10(2), 89-96.

Stenvall, J. \& Vitanen, P., 2017, 'Intelligent public organisations', Public Organisation Review 17(2), 195-209.

Swailes, S., 2020, 'Responsible talent management: Towards guiding principles', Journal of Organizational Effectiveness: People and Performance 7(2), 221-236. https://doi.org/10.1108/JOEPP-04-2020-0068

Swailes, S., Downs, Y. \& Orr, K., 2014, 'Conceptualising inclusive talent management: Potential, possibilities and practicalities', Human Resource Development International 17(5), 529-544.
Thunnissen, M. \& Buttiens, D., 2017, 'Talent management in public sector organizations: A study on the impact of contextual factors on the TM approach in Flemish and Dutch public sector organizations', Public Personnel Management 46(4), 1-28. https://doi.org/10.1177/0091026017721570

Tsai, Y., 2011, 'Relationship between organizational culture, leadership behavior and job satisfaction', BMC Health Services Research 11(98), 1-11.

Tshukudu, T., 2020, 'An evaluation of a reward management system used by the Botswana Local Authority: The case of Gaborone City Council', Internationa Journal of Sciences: Basic and Applied Research 50(2), 124-134.

Tuurnas, S., Stenvall, J., Virtanen, P.J., Pekkola, E. \& Kurkelam, K., 2019, 'Towards collaborative development culture in local government organisations', International Journal of Public Sector Management 32(6), 582-599. https://doi. org/10.1108/JJPSM-05-2018-0119

Uddin, M.J., Luva, R.H. \& Hossian, M., 2013, 'Impact of organisational culture on employee performance and productivity. A case study of Telecommunication Sector in Bangladesh', International Journal of Business and Management 8(2) 63-77. https://doi.org/10.5539/ijbm.v8n2p63

Van Antwerpen, S. \& Ferreira, E., 2016, 'Contributing factors to poor service delivery by administrative employees in the Gauteng Public Service in South Africa', Africa Development XLI(1), 81-98.

Welby-Cooke, G., 2010, 'The psychometric properties of a talent mindse index', Upublished masters dissertation, University of Pretoria, Pretoria.

Yahiaoui, N., Anser, A. \& Lahouel, S., 2015, 'Human resource management and public organisations', Global Journal of Human Resource Management 3(2), 1-12.

Yosinta, O., 2016, 'Organisational culture and good governance in the public sector: The case of provincial administration in Thailand', Unpublished doctoral thesis, University of Birmingham, Birmingham.

Zain-Ul-Abidin, R, Qammar, R. Nadeem, S. \& Farhan, H, 2020, 'Effect of organization culture on public sector organizational performance: A case of Jordan', International Journal of Academic Management Science Research $4(5), 1-10$.

Zydziunaite, V., 2018, 'Leadership values and values based leadership: What is the main focus?', Applied Research in Health and Social Sciences: Interface and Interaction 15(1), 43-58. https://doi.org/10.2478/arhss-2018-0005 